\title{
Managing The Legal Risks Of High-Tech Classrooms
}

\author{
Laura A. Nenych, B.A.A., J.D., LL.M., Ryerson University, Canada
}

\begin{abstract}
When professors and students utilize the Internet, course web pages, and other online learning tools, much of the material that they make use of is protected by copyright law. A blend of case law and legislation governs the use of online materials and how technology can be used in the classroom and in school-related activities, often creating confusion for content users. Educators and students alike need to be familiar with applicable laws and need to understand the implications of common activities such as using technology in the classroom, conducting research on the Internet, and using multi-media in classroom presentations and student projects. Canadian copyright law is currently undergoing a much-needed process of reform, in order to bring Canadian copyright law in line with the laws of the rest of the world, and to keep up with rapidly changing technology that has changed the way people use copyrighted materials. This paper will focus on the legalities surrounding the use of technology and digital media in educational settings. It will provide guidelines for Canadian educators to ensure that their use of information technology and digital materials in the classroom is both appropriate and acceptable, and will propose strategies to manage those risks.
\end{abstract}

Keywords: Copyright; Technology; Education; Canada

\section{INTRODUCTION}

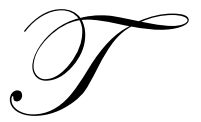

here is a significant trend among educators to incorporate the Internet and other online communication tools, such as course web pages, when they plan their courses. Although these tools help students to communicate, collaborate and access information more efficiently, they present challenges to educators who feel compelled to redesign courses to fit the needs of a new generation of students, many of whom have never experienced a world without computers, the Internet, interactive video games, cell phones, texting, and instant messaging. Indeed, university students expect that technology will be used in the classroom, and believe that they aren't getting full value for their money if technology isn't used. ${ }^{1}$ However, while students are primarily concerned with how a course is delivered (and with the ease of access to course information), the faculty member must also be cognizant of the legalities involved in delivering a course using the most current technology. Ignorance of the law will not protect a faculty member against charges of copyright infringement, which carry severe penalties ranging from civil damages to criminal prosecution.

One of the most important factors to consider is how intellectual property laws apply to the proposed course content. "Intellectual property" is the legal term for an idea or knowledge that has been expressed in tangible form, and therefore, has an owner. Copyright issues are among the most common legal questions faced by educators. Copyright, a type of intellectual property, provides the legal framework within which creators of literary, artistic, and musical works are able to receive remuneration for, and protect the integrity of, the works that they have created. As this creative expression more frequently takes on a digitized format, the traditional rules of copyright do not always provide a good working balance between protecting the rights of the creator with the needs of those who wish to access the copyrighted content. This need for balance is particularly evident in an educational setting.

${ }^{1} \mathrm{http} / / /$ www.educause.edu/Resources/EducatingtheNetGeneration/TechnologyandLearningExpectati/6056 (accessed December 1, 2009.) 


\section{COPYRIGHT ISSUES FACED BY CANADIAN EDUCATORS}

One of the main purposes of copyright law is to promote creation in the arts and science communities, by giving creators certain exclusive rights to their works. One of the Canadian government's stated goals is to ensure that "[c]opyright protection rewards the creation and dissemination of knowledge and cultural content, and facilitates access to this knowledge and content." ${ }^{2}$ Copyright laws are economic in nature, and by conferring rights on owners and/or creators, they can also discourage others from creating illegal copies of another's intellectual property. On the other hand, copyright laws must balance the rights of creators with those of users of content, ensuring that the public can gain access to works that will enrich the culture of the entire country. However, technological advances related to the Internet, digital distribution, and a digital marketplace have placed enormous demands on the courts and content users to interpret outdated copyright laws, which have failed to keep up with these technological changes. It has become a simple process to digitize a work and to make unauthorized reproductions, and to distribute those reproductions around the world.

In simplified terms, "copyright" simply means the right to copy. Copyright is often referred to as a "bundle of rights." In Canada, the Copyright $A c t^{3}$ confers several exclusive rights upon copyright owners, including the following:

- $\quad$ the right to reproduce the work

- $\quad$ the right to distribute copies of the work

- $\quad$ the right to perform the work publicly

- $\quad$ the right to make a derivative work

- $\quad$ the right to display the work publicly

Copyright subsists in various forms of dramatic, literary, artistic, and musical works, including books, plays, musical compositions, sculptures, paintings, films, and computer programs. Only the expression of the idea is given protection under copyright law, as the idea itself, information, and facts cannot be copyrighted. Copyright laws also make it illegal to reproduce or publicly perform these copyrighted original works without the permission of the copyright owner. Most faculty members are aware that they cannot simply make copies of entire textbooks to be distributed to their students. However, many are somewhat confused as to what, exactly, is allowed when posting materials on course websites, making use of the Internet in the classroom, showing video clips in class, and when students use copyrighted works in their student presentations. The public performance right, in particular, has implications in the classroom, as the simple action of showing a work in class may entail copyright infringement. Therefore, as technology is used more and more in classrooms, it creates opportunities for enhanced student learning, but also creates challenges because of the complexities involved when technology and online materials are used for educational purposes. The answer to these challenges, of course, is not to stop digitization or the use of such materials in the classroom, as there is a perfectly valid purpose behind such use, which ought to be encouraged. What is needed is a clear set of laws and simple procedures that will allow students to benefit from the vast range of materials available, while also ensuring that creators are able to protect their creations, and receive economic benefit from them. If the proper balance is found, creators and users will both be able to exploit the potential of the Internet.

The following are several issues faced by educators, as well as suggestions on how to handle them.

As a faculty member, working in an educational institution and acting under its authority, what can I do in that that will not infringe copyright?

There are several things that you can legally do.

(a) use any work protected by copyright, with the express written permission of the copyright owner

(b) copy or perform works whose author(s) died more than 50 years ago (but not translations or annotations of such works)

\footnotetext{
${ }^{2}$ http://strategis.ic.gc.ca/epic/internet/incrp-prda.nsf/en/rp01101e.html (accessed December 1, 2009.)

${ }^{3}$ http://laws.justice.gc.ca/en/C-42/ (accessed December 1, 2009.)
} 
(c) copy a work protected by copyright by hand onto a surface normally used to display handwritten material, such as a blackboard, whiteboard, or flip chart

(d) copy a work protected by copyright for the purpose of overhead projection using a device such as an LCD, overhead, opaque, or slide projector, provided the work is used for the purpose of education and training and is not already available in a commercial format

(e) make a single copy of works, such as articles or photographs, protected by copyright for private study, research, criticism, review, or news reporting under the "fair dealing" sections of the Copyright Act that allow such uses of copyright material

(f) use the fair dealing exception to copy and perform extracts from a work protected by copyright, unless the part is highly significant or valuable (courts make the final determination whether a "dealing" is "fair")

(g) copy an entire work (other than a cinematographic work) onto an alternative format including translation, adaptation, and performance in public (except the making of a large-print book) for the purpose of serving students with perceptual disabilities, as long as such an adaptation is not already commercially available in that format

(h) copy the text of federal and Ontario statutes, regulations, and court decisions (but not other materials produced by Canadian governments) without permission ${ }^{4}$

Some of the more complex provisions will be described in more detail below.

\section{What is the "public domain"?}

In Canada, a work is in the public domain once the term of copyright protection has expired -- most often, 50 years after the death of the author. Any work that is in the public domain is available for anyone to use, without asking for permission or paying royalties. Material that was produced by the US government is freely available for the public to use. However, there is no such provision for materials produced by Canadian governments. A work can also be placed in the public domain by the copyright holder, at any time, provided such a transfer is in writing. For example, Creative Commons licenses allow creators to communicate which rights they reserve, and which rights they waive for the benefit of recipients or other creators.

\section{What is the "exception" for educational institutions?}

The Canadian Copyright Act contains exceptions for certain categories of users. Educational institutions are permitted to make very specific use of works protected by copyright if they are done on the premises of an educational institution for educational or training purposes, provided there are no suitable substitutes available in the commercial marketplace.

Section 29.4 of the Act provides an exception for educational institutions, and those working under their authority to do the following things without seeking permission or paying royalties to the copyright holder: "(a) to make a manual reproduction of a work onto a dry-erase board, flip chart or other similar surface intended for displaying handwritten material, or (b) to make a copy of a work to be used to project an image of that copy using an overhead projector or similar device; for the purposes of education or training on the premises of an educational institution." 5 It also allows professors to reproduce a work for a test or examination.

\section{May I play music, radios, or televisions in the classroom?}

Yes, there is an exception that permits the playing of sound recordings in the classroom for educational purposes. (Note that this exception only allows for the playing of sound recordings, and not the editing of the sound recording.) Educational institutions may also copy news and news commentary (excluding documentaries) from radio and television broadcasts and keep the copy for educational use on school premises for up to one year from the date the tape is made. All other types of radio and television broadcasts can be copied by educational institutions and kept for up to 30 days to decide whether the copy will be used for educational purposes. If the copy is used for

\footnotetext{
${ }^{4} \mathrm{http}: / /$ www.cmec.ca/Publications/Lists/Publications/Attachments/12/copyrightmatters.pdf page 5 (accessed December 3, 2009)

${ }^{5} \mathrm{http} / /$ www.cipo.ic.gc.ca/eic/site/cipointernet-internetopic.nsf/eng/wr00506.html\#no6 (accessed December 1, 2009) 
educational purposes, a royalty set by the Copyright Board must be paid. The playing of sound recordings and of radio and television programs, as well as the performance of works such as a play, are subject to all of the following conditions:

(a) must take place on the premises of an educational institution

(b) must be for educational or training purposes (and not for extracurricular activities)

(c) must not be for profit

(d) must take place before an audience consisting primarily of students of the educational institution, instructors acting under its authority, or any person who is directly responsible for setting curriculum

(e) must not involve a "motive of gain"

(f) All tapes recorded for evaluation purposes must be clearly marked with the Title; Air Date; Air Time; Broadcaster (or channel); Duration of segment.

I would like to show my students clips from several films that I own. I would like to copy the clips onto a single DVD for ease of presentation. May I show a movie in class that I rented from Blockbuster?

You can show these only if your school has purchased the public performance rights for the films, as all videos shown in the classroom must have cleared public performance rights. Contact your school's library for further assistance. Some videos can be rented or purchased with public performance rights already included. Make sure you are given written permission when purchasing or renting and keep this agreement on file.

\section{May I scan a graph or photo from a textbook and use it in my PowerPoint presentation?}

If the PowerPoint will be shown only in class, then, generally, yes you may. However, putting your PowerPoint presentation up on the course website, even if access is restricted to those in the course, is not permitted. You would also not be permitted to make handouts of your slides, without getting express permission from the copyright owner.

\section{Can my students and I use material copied from the Internet?}

Copyright law applies on the Internet, just as it does to paper materials. It may be an infringement of copyright to post material on a website, for example, without the consent of the copyright owner. The general rule is that you must get permission from the owner (usually the person or organization that created the material) to use text, graphics, images, sound and video that have been created by others. There are some things that are not usually protected by copyright, for example, facts, information, titles, ideas, plots, short word combinations, and works in the public domain. You may use these freely.

\section{May I provide my students with a link to a website?}

Instead of copying materials to post on a course website, it may be preferable to provide a link to legitimately available materials on the Internet. Although it is always preferable to seek permission, it is very unlikely that there will be any copyright infringement if you simply post a link to a normal entry point for a website. You should not link to an "internal" page or to an individual graph or photo on a website. Of course, if there is a notice on the website that indicates permission to link is required, then you must seek such permission.

\section{Can my school's library do anything to assist me, if I need something done that I am not allowed to do?}

Yes, often a school library can do things that you, as a faculty member, cannot. Exceptions under the Copyright Act permit additional things to be done by libraries, including those in schools, that would infringe copyright if there were no exceptions. These include the following:

(a) making a copy of a work "if the original is rare or unpublished and is deteriorating, damaged, or lost" provided a replacement copy is not commercially available 
(b) making a copy of a fragile document for on-site consultation if the original cannot be viewed because of its condition - provided a replacement copy is not commercially available

(c) making a copy if the original is in an obsolete format or the technology to use the original is unavailable provided a replacement copy is not commercially available

(d) making a copy for the purpose of cataloguing or internal record keeping or for insurance purposes or police investigation

(e) making a copy for the purpose of restoration ${ }^{6}$

\section{What is the difference between "fair use" and "fair dealing"?}

Fair use is an American copyright concept and it does not apply to Canada. The Canadian "Fair dealing" exception is much more limited in scope than "fair use" is. Case law has shown that courts allow for fair dealing in the context of "private study" and "private research", and therefore, while these provisions are useful for researchers and for students writing term papers, the exception has limited application to what professors can do with copyrighted materials in a classroom setting.

\section{When does fair dealing apply, and what test is used?}

Under the fair dealing provision, it may not be infringement to quote or copy small parts of a work, if the purpose of the copying is for private study, review, research, or criticism. There are very specific criteria to be met to qualify for the fair dealing exemption.

In CCH Canadian Ltd. v. Law Society of Upper Canada ${ }^{7}$ (hereinafter CCH), the Supreme Court of Canada released a unanimous decision that clarified the test for fair dealing. The Court established that the exemption for fair dealing includes copying for research conducted for commercial purposes, and it made several important statements with respect to the policy reasons underlying copyright law. First, the Court indicated that, in interpreting the Copyright Act, Canadian courts should strive to maintain an appropriate balance between the two main goals of copyright: (a) supporting the public interest in promoting the dissemination of works of creators, and (b) ensuring that creators are justly rewarded for the use of their works.

In this same decision, the Court considered the interpretation of the "fair dealing" exemption set out in Section 29 of the Act. The Court set out a two-part test to determine whether a specific use should fall under Section 29. First, the defendant must prove that the work was used either for research or for private study. The Court gave "research" a broad interpretation, in an effort to ensure that users were not unfairly restricted in their uses of works; more specifically, the Court held that the term "research" would include that done in a commercial setting, or for a commercial purpose.

The second part of the test requires the defendant to prove that his or her use is "fair." A test for fairness set out by the Federal Court of Appeal was accepted as appropriate by the Supreme Court. Factors to be considered include the following:

(1) the purpose of the dealing;

(2) the character of the dealing;

(3) the amount of the dealing;

(4) alternatives to the dealing;

(5) the nature of the work; and

(6) the effect of the dealing on the work.

The Court further held that one is not liable for "authorizing copyright infringement" merely by providing equipment (in this case photocopiers) that could be used by others to infringe copyright. $\mathrm{CCH}$ allowed libraries to provide equipment that could be used to infringe copyright, but the Court held that the libraries could rightfully

\footnotetext{
${ }^{6} \mathrm{http}: / /$ www.cmec.ca/Publications/Lists/Publications/Attachments/12/copyrightmatters.pdf page 6 (accessed December 3, 2009) ${ }^{7}$ [2004] 1 S.C.R. 339 [CCH] 
assume that their equipment would be used in a lawful manner, and that users of the equipment would comply with the provisions of the Copyright Act.

\section{What if I need to copy more than fair dealing allows?}

The Copyright Act permits copyright collectives to collect copyright payments on behalf of copyright owners, and to authorize the use of their works. For published works, most universities and colleges in English Canada have paid for blanket licences with Access Copyright, which cover copying of published material by photocopying, facsimile, or similar methods of copying. The blanket licences generally limit copying as follows:

No copying shall exceed $10 \%$ of a published work or the following (whichever is greater):

(a) an entire newspaper article or a page;

(b) an entire single short story, play, poem, essay or article from a book or periodical issue (including a set of conference proceedings) containing other works;

(c) an entire chapter which is $20 \%$ or less of a book

Certain categories of works are not covered by the licence; for example, digital reproductions, unpublished works, and sheet music are not covered by the blanket licence. If a professor or student needs to make a digital copy, or needs to make a copy of an unpublished work or sheet music, permission must be granted from the copyright owner. In the alternative, for digitized extracts from books, journals or periodicals to be placed on an intranet, the copyright owner's consent may be obtained under an Access Copyright digital pay-per-use license.

\section{What are some of the things that can't I do?}

Some copying activities in universities are not covered by the concept of fair dealing or the Access Copyright blanket license. These include:

(a) copying an entire book;

(b) repeated, systematic and cumulative copying from the same published work

(c) copying that would eventually result in a substantial part of that work being copied;

(d) copying published sheet music or workbooks;

(e) copying of unpublished works, such as private letters, diaries, or class notes. ${ }^{8}$

\section{SUMMARY}

Canadian copyright law is currently undergoing a much-needed process of reform, in order to bring Canadian copyright law in line with the laws of the rest of the world, and to keep up with rapidly changing technology that has changed the way people use copyrighted materials. It is clear that there are several issues with respect to copyright reform that are of particular importance to the academic community. The first is that the Copyright Act must be amended to allow fair and reasonable educational uses of materials found on the Internet that have been made publicly available by the copyright owner, who has no expectation of payment for the use of such materials. Second, copyright laws must allow for the easy use of technology to enhance student learning. In particular, it is important to ensure that Canadian copyright laws provide adequate access to copyrighted materials to facilitate distance learning courses, where materials and coursework are delivered over the Internet. Third, faculty and students must be allowed to take advantage of technology to deliver programs inside the classroom.

Until the Copyright Act is amended to facilitate use of materials in educational settings, it is important to keep in mind that making unauthorized copies of copyrighted materials poses legal risks, which include injunctions, damages, costs, and possible criminal sanctions. As a faculty member, your best defense is to set a clear policy against copyright infringement in your classroom. It is important for you to become aware of copyrighted materials on your course web pages and your online teaching tools, and to ensure that you delete unauthorized copies of copyrighted material, to protect yourself as well as your educational institution.

\footnotetext{
${ }^{8}$ http://www.aucc.ca/_pdf/english/publications/copying2002_e.pdf (accessed December 1, 2009)
} 


\section{AUTHOR INFORMATION}

Laura Nenych Since 2003, Laura Nenych has been a full-time professor at Ryerson University and is currently the Director, Graduate Program in Media Production. She teaches Entertainment Law, Media Management, The Business of Music, and Audio Production at both the graduate and undergraduate levels, and sits on the Ryerson Research Ethics Board. Prior to joining Ryerson, she was the Director, Legal and Business Affairs at EMI Music Canada/Capitol Records/Virgin Records. Professor Nenych's research interests include copyright reform, broadcasting policy, e-commerce, and how new technologies and the Internet affect the international entertainment industry. She continues her part-time practice in law, representing entertainment clients.

\section{NOTES}




\section{NOTES}

